\title{
The Value of Green: The Effect of Environmental Rankings on Market Cap
}

\author{
Nathan Troutman Blumenshine ${ }^{1}$, Phanindra V. Wunnava ${ }^{1,2}$ \\ ${ }^{1}$ Economics Department, Middlebury College, Middlebury, Vermont, USA \\ ${ }^{2}$ IZA (Institute for the Study of Labor), Bonn, Germany \\ E-mail: nateblumenshine@gmail.com,wunnava@middlebury.edu \\ Received June 24, 2010; revised July 22, 2010; accepted July 26, 2010
}

\begin{abstract}
This study empirically examines the relationship between environmental rankings and market cap value. The financial indicators of the Altman Z-Score are used to build a model for market cap value. The data used is from 2000-2008 for 100 of the companies included in Newsweek's Top 500 Green Rankings 2009. The results support the hypothesis that companies with high environmental rankings have higher market cap values than comparable companies with lower rankings. This shows that either investors are including environmental factors in their stock price valuations, or that a high environmental rank indicates other intangible variables that contribute to a company's value.
\end{abstract}

Keywords: Environmental, Financial, Market Cap, Panel Data

\section{Background}

There is a growing global awareness about the negative effects that business can have on the environment. Some production processes release toxins that cause cancer, others emit carbon dioxide that could lead to global climate change. In response to these perceived threats to the environment, investors, and their clients, are looking for strategies to curb these negative effects by using the power of the market. In January 2007, \$2.71 trillion worth of invested assets were involved in some sort of environmental or social screening, shareholder advocacy or community investment strategy. This is out of the $\$ 25.11$ trillion total tracked in Nelson Information's Directory of Investment Managers. In addition, there has been tremendous growth, from $\$ 12$ billion in 1996 to $\$ 201.8$ billion in 2007, in the assets invested in environmentallyor socially-responsible mutual funds - Social Investment Forum [1]. In 2009, 90\% of investment consultants responded that their clients have brought up environmental, social or governance issues as being important to their investment strategy as per Kropp [2]. This increase of interest has inspired a lot of research on the financial performance of socially responsible techniques.

Different studies have taken a variety of approaches to calculate the effects of using environmental and social criteria in portfolio management. Previous studies include: constructing a comprehensive universe of mutual funds and comparing the performance of SRI funds to the others - Geczy, Stambaugh and Levin [3], using time-factor analysis to measure the learning effect from old to new ethical funds - Bauer, Koedijk and Otten [4], and measuring the risk-adjusted return of the alternative energy industry compared to a benchmark - MSCI Barra [5]. This study was inspired principally by the work of Statman and Glushkov [6], who constructed a Best-in-Class portfolio based on different SRI factors from the S \& P 500. To measure the effect of environmental performance on returns, they took the top $3^{\text {rd }}$ of the S \& P 500 universe based on their rankings and compared it to a portfolio constructed out of the bottom $3^{\text {rd }}$. Their study showed a slight but significant increase, $0.42 \%$ to $2.69 \%$, in the performance of highly-ranked stocks compared to their low-ranking counterparts as per Statman and Glushkov [6]. The explanation for these higher returns is that environmental ranking could indicate other intangible variables that add to a company's value, such as good management, committed consumer base and lower legal expenses.

The goal of this project is to determine whether the increase in investor use of extra-financial criteria has had any effect on the market value of companies. In doing so, it contributes to the literature supporting the enhanced value of companies that consider environmental impact 
as part of their business plan compared to those that do not.

\section{Data and Methodology}

This study uses panel data for 100 companies over a 9-year period from 2000-2008 ${ }^{1}$. Using panel data has a variety of estimation benefits and challenges. Panel data provides more data points and thus increases the number of degrees of freedom ${ }^{2}$. Unfortunately, using panel data presents the challenge of dealing with heteroscedasticity and serial correlation simultaneously. To solve this problem we used a generalized least squares method that accounts for heteroscedasticity and serial correlation ${ }^{3}$.

This study uses a similar methodology to the Statman and Glushkov [6]. First, we divide the companies into two groups according to environmental performance. Then, we compare the two groups using a financial metric. Unlike Statman and Glushkov [6], who use the returns of each portfolio to compare the two groups, we used Market Cap for individual companies as our financial metric. The Market Cap is the total value of a firm's assets, revenue stream, risk and future growth, as it is valued by investors in a public stock market. Therefore, it is an appropriate dependent variable for this study because how different variables affect it is of great interest to investors.

Building a model for Market Cap is challenging because of the uncertainty in the stock market. If one model could capture the value of a company perfectly based on

\footnotetext{
${ }^{1}$ The financial data collected for this study came from Mergent Online and Bloomberg. However, not all companies reported data for every year. Due to missing values, in the end we were left with 433 observations for 70 companies covering two to nine years of data.

${ }^{2}$ Due to the time-invariant nature of our key variable 'Green'-we could not employ a fixed effects type of methodology. Further, given the severe fluctuations in the stock market and widely-varying market cap values, using an 'OLS' method is inappropriate because it does not account for serial correlation or heteroskedasticity.

${ }^{3}$ This technique subjects the observations to two transformations, one to remove heteroscedasticity, and the other to remove autocorrelation. In essence, this technique comes up with a disturbance term $\left(\varepsilon_{\mathrm{it}}\right)$ that is both asymptotically non-autoregressive and homoscedastic. First, OLS is used to obtain the regression residuals, which are then used to perform transformations to obtain an asymptotically nonautoregressive and homoscedastic error term (for details see Kmenta [7], pp. 618-22). The characteristics of this model are as follows:

$$
\begin{aligned}
& E\left(\varepsilon_{\mathrm{it}}^{2}\right)=\sigma_{\mathrm{i}}^{2} \text { (heteroscedasticity) } \\
& E\left(\varepsilon_{\mathrm{it}}, \varepsilon_{\mathrm{jt}}\right)=0
\end{aligned}
$$

(where $i \neq j$ denotes cross-sectional independence - no autocorrelation across companies in a given time period) where

$$
\varepsilon_{\mathrm{it}}=\rho \varepsilon_{\mathrm{t}, \mathrm{t}-1}+\mathrm{u}_{\mathrm{it}}
$$

(where autocorrelation is concerned, $\rho$ is assumed to be constant across the cross-sectional units,

and $u_{i t}$ is the classical error term)

and $\mathrm{E}\left(\varepsilon_{\mathrm{i}, \mathrm{t}-1}, \mathrm{u}_{\mathrm{jt}}\right)=0$ for all $\mathrm{i}, \mathrm{j}$
}

a set of financial indicators, then the market would become obsolete because there would be no unpredictable fluctuation in stock price to encourage investors to take on risk. Nevertheless, there are financial indicators that strongly suggest the value reflected by the market cap. The statistical model used in this study is based on the Altman Z-Score and Newsweek's Top 500 Green Rankings 2009.

The Altman Z-Score was developed as an indicator of company risk and bankruptcy likelihood. It has credibility within the financial community with a proven track record of $72 \%$ accuracy in predicting firm bankruptcy, and has financial indicators that are proxies for the fundamental valuation of a company. For this study we made Market Cap a dependent rather than independent variable because the other variables in the Altman Z-Score are proxies for essential elements that affect the valuation of a company, such as growth potential, risk, assets and revenue stream. These statistics are Working Capital, Retained Earnings, Earnings before Interest Taxes Depreciation and Amortization, Sales, Total Liabilities, and Total Assets ${ }^{4}$. This is appropriate because in developing the Altman model, these variables all tested highly significant in predicting the financial health of a firm ${ }^{5}$.

In order to capture the impact of environmental ranking this study adds a 'green' dummy variable to the Altman Z-Score model. The ranking system used in this study is Newsweek's Top 500 Green Rankings 2009. The environmental scores are a weighted combination of several different environmental performance factors ${ }^{6}$. The Environmental Impact Score measured $\mathrm{CO}_{2}$ emissions, water use, solid waste, and acid rain emissions, normalized according to revenue. The Green Policies Score was based on corporate policies addressing climate change, pollution, product impact, and environmental stewardship. The Reputation Score was compiled from an opinion survey that received 808 responses from professionals, academics and environmental experts. All of the scores were transferred onto a 100 point scale for relative comparison between companies. The final rank was determined by giving a $45 \%$ weight to Environmental Impact, $45 \%$ to Green Policies and 10\% to Reputation as suggested by McGinn [9].

\footnotetext{
${ }^{4}$ Sales, a variable from the Altman model was dropped from our model because of a high correlation with Earnings before Interest Taxes Depreciation and Amortization.

${ }^{5}$ The Z-Score was originally developed by Edward Altman in 1968 to measure the risk of investing in manufacturing companies. Since then it has been modified for different industries and market areas Altman [8].

${ }^{6}$ The factors were developed by three different research firms. KLD Research and Analytics, tracks environmental, social and governance data for companies worldwide. Trucost measures quantitative environmental performance such as $\mathrm{CO}_{2}$ emissions and resource use. CorporateRegister.com is an online directory for social and environmental responsibility reporting.
} 
The Newsweek report included 500 companies in its survey but this study only used 100 of them. The top 50 companies on the list were given a green dummy value of 1 . The last 50 in the list were given a green value of 0 . The final model used in this study is as follows:

$$
\begin{aligned}
\operatorname{lnMC}_{\mathrm{it}}= & \beta_{0}+\beta_{1}(\operatorname{lnEBITDA})_{\mathrm{it}}+\beta_{2}(\operatorname{lnSE})_{\mathrm{it}} \\
& +\beta_{3}(\ln W \mathrm{C})_{\mathrm{it}}+\beta_{4}(\operatorname{lnRE})_{\mathrm{it}} \\
& +\beta_{5}(\text { green })_{\mathrm{it}}+\varepsilon_{\mathrm{it}}
\end{aligned}
$$

where $\mathrm{i}=1,2,3 \ldots 100$ (i.e., 100 companies) and $\mathrm{t}=$ 2000, 2001, ... 2009 (i.e., 9 years)

$\mathrm{MC}=$ Market Cap, EBITDA $=$ Earnings before Interest Taxes Depreciation and Amortization, $\mathrm{SE}=$ Shareholders Equity ${ }^{7}, \mathrm{WC}=$ Working Capital, and $\mathrm{RE}=\mathrm{Re}-$ tained Earnings. Given the double log nature of the model, the estimated coefficients can be treated as constant elasticities.

\section{Empirical Analysis}

The sample characteristics are presented in Table $\mathbf{1}$ and the regression results in Table 2.

Table 1. Sample characteristics [sample size $=433$ ]

\begin{tabular}{ccccc}
\hline Variable & Mean & Std. Dev. & Min & Max \\
\hline $\operatorname{lnMC}$ & 23.33999 & 1.253418 & 20.2686 & 26.8127 \\
$\operatorname{lnEBITDA}$ & 20.99451 & 1.208203 & 17.4943 & 23.7178 \\
$\operatorname{lnSE}$ & 22.21777 & 1.103579 & 19.3253 & 25.0384 \\
$\operatorname{lnWC}$ & 20.99383 & 1.408282 & 15.2018 & 24.7414 \\
$\operatorname{lnRE}$ & 21.30987 & 1.349212 & 16.3805 & 24.4171 \\
green [dummy & 0.536364 & 0.499244 & 0 & 1 \\
\hline
\end{tabular}

Table 2. Generalized least squares heteroskedastic panels autocorrelation corrected results.

Dependent Variable: InMC

\begin{tabular}{cccc}
\hline Variable & Estimated Coefficient & $\mathbf{z}$-value & $\mathbf{p}>|\mathbf{z}|$ \\
\hline $\operatorname{lnEBITDA}$ & 0.1784954 & 6.15 & 0.000 \\
$\operatorname{lnSE}$ & 0.5688896 & 13.11 & 0.000 \\
$\ln \mathrm{WC}$ & 0.034249 & 2.03 & 0.043 \\
$\ln \mathrm{RE}$ & 0.495783 & 1.96 & 0.050 \\
green [dummy] & 0.6220458 & 10.91 & 0.000 \\
constant & 4.81318 & 8.58 & 0.000 \\
\hline
\end{tabular}

Wald $\chi_{[5]}^{2}=1798.46[p$-value $=0.000]$

${ }^{7}$ Shareholders Equity $=$ Total Assets — Total Liabilities
EBITDA, earnings before interest, taxes, depreciation and amortization, measures a firm's productivity. Shareholder's Equity, measures how much a firm's assets can decline before the company becomes insolvent. Working Capital, current assets minus current liabilities, is a measure of the net liquid assets a company has at its disposal to cope with any unexpected contingencies. Retained Earnings is a measure of the leverage a firm has in terms of how much it has financed its assets through profits versus taking on debt. We expect the coefficients of all these variables to be positive because they are positively related to the financial health of the firm and thus increase a firm's value to investors.

The $95 \%$ confidence interval for the green coefficient is 0.6220458 . This means that a green company is predicted to have an $86.3 \%$ greater Market Cap than a nongreen company with the same financial indicators ${ }^{8}$. The estimated coefficients for the financial statistics are also all significant, and make economic sense.

This is a very positive finding in terms of the value of green investing. It shows that companies with high environmental scores are considered to be more valuable to investors than companies with similar financial statistics that have low environmental scores. This could be because high environmental rankings represent a proxy for other characteristics that add value to a firm. These characteristics include: better management, better brandname, fewer lawsuits, and transparent records, among other things. This is the rationale behind Environmental, Social and Governance (ESG) analysis that has become a widespread method among investors for considering the extra-financial characteristics of firms in each of these areas as value indicators. Admittedly, other characteristics such as size could be influencing this positive result as well. A bigger company will be more concerned with reputation and have more money to spend promoting a positive environmental image even if it is more environmentally destructive than its smaller competitors. Future studies will have to determine the true impact of the other variables not accounted for in this model, but the initial findings suggest that the effect of being green on firm value is significant and positive.

\section{Conclusion \& Next Steps}

This study concludes that there is value in being green.

\footnotetext{
${ }^{8}$ Given the log-lin nature of the model, in order to interpret this component we need to scale it as: $\left[\mathrm{e}^{(0.6220458)}-1\right] \times 100 \%=86.3 \%$

${ }^{9}$ As pointed out by the referee of this journal, a firm's market value (and hence market capitalization) will also be affected to some extent by other factors than those used in the empirical model. The most frequently used valuation model is the Tobin's q theory, including variables such as firm's growth potential (proxied by market to book value ratio or sales growth rate); capital expenditures and R \& D expenses, financial risk (proxied by debt ratio); and firm's stock risk and/or operating risk (proxied by earnings volatility), among others.
} 
Investors are willing to pay a premium for the ownership of a company with higher environmental rankings relative to a company with similar financial characteristics but a lower ranking. The results from this study are that a 'Green' company indicates an increase in Market Cap value of $86.3 \%$ over a non-green company. We should be cautious with this conclusion for several reasons.

First, this model uses just one set of financial indicators that investors consider when valuing companies. Future studies using models made up of other financial statistics need to be conducted before drawing any final conclusions. Second, there are many factors that contribute to the value of a company that are not in the financial statements, such as management quality, geographic location, industry, age and many more ${ }^{9}$. The correlation of these variables with our dummy variable 'Green' should be measured and if appropriate added to the model. Third, the ranking system used is just one of many ways of ranking companies based on environmental performance, and it was time-invariant. Other ranking systems that show variation over time should be used to show how investors react to particular companies as they enact more environmentally positive policies.

Hopefully, the results from this study will inspire future research. If environmental ranking is a good indicator of value, more resources should be directed into this type of research. If this positive relationship between 'Green' and Market Cap is borne out, then more investors will start using ESG analysis in their investment strategies. As companies realize that environmental ranking will boost their value to investors they will start adopting more environmentally friendly policies. Rather than destroying value, corporate environmental practices could create it. In this way, the power of demand could reduce the negative externalities of some business processes on the environment without creating additional costs for anyone.

\section{Acknowledgment}

Data used for this project was collected with the help of Scott Pardee, Brenda Ellis and Matthew Park. Further, we would like to thank an anonymous referee of this journal for his/her constructive suggestions, William Warren for his excellent editorial insights, and Hans Raum for his timely research assistance. The usual caveats apply.

\section{References}

[1] Social Investment Forum, "2007 Report on Socially Responsible Investing Trends in the United States," 2007. http://www.socialInvest.org/pdf/SRI_Trends_ExecSumm ary_2007.pdf

[2] R. Kropp, "Investment Consultants Believe that ESG Considerations by Investors Are Here to Stay," Sustainability Investment News, December 3, 2009. http://www.socialfunds.com/news/article.cgi/ 2836.html

[3] C. Geczy, R. F. Stambaugh and D. Levin, "Investing in Socially Responsible Mutual Funds," 2005. http://papers.ssrn.com/sol3/papers.cfm?abstract_id $=4163$ 80

[4] R. Bauer, K. Koedijk and R. Otten, "International Evidence on Ethical Mutual Fund Performance and Investment Style," Journal of Banking and Finance, Vol. 29, 2005, pp. 1751-1767.

[5] MSCI Barra, "Is there a Green Factor?" October 2008. http://www.responsi.ble-investor.com/images/uploads/res ources/research/21224975267MSCI_Barra_Is_There_A_ Green_Factor.pdf

[6] M. Statman and D. Glushkov, "The wages of social responsibility," December 2008.

http://papers.ssrn.com/sol3/papers.cfm?abstract_id=1372 848

[7] J. Kmenta, "Elements of Econometrics," 2nd edition, Macmillan, New York, 1986.

[8] E. Altman, "Revisiting Credit Scores in a BASEL 2 Environment," In: M. K.Ong, Ed., Credit Rating: Methodologies, Rationale and Default Risk. Risk Books, London, 2002, pp. 151-168 http://www.stern.nyu.edu/fin/workpapers/papers2002/pdf /wpa02041.pdf

[9] D. McGinn, "The Greenest Big Companies in America: Newsweek's Top 500 Green Rankings 2009," Newsweek, Vol. 154, No. 13, September 28 2009, pp. 34-44, 48, 52-54. http://www.greenrankings. newsweek.com/top500 